\title{
Księgozbiór Zbyszewskich i Iżyckich w zbiorach Miejskiej Biblioteki Publicznej im. Juliusza Słowackiego w Tarnowie
}

Miejska Biblioteka Publiczna im. Juliusza Słowackiego (MBP w Tarnowie) jest jedną z bibliotek publicznych w Małopolsce mogących poszczycić się zbiorami interesującymi z perspektywy historii książki. Ich główny zręb stanowią kolekcje podworskie, które biblioteka uzyskała po upaństwowieniu lokalnych majątków ziemskich w 1945 r. Najcenniejsza z nich to fragment biblioteki rodowej Sanguszków z Gumnisk. Inne, nie mniej ciekawe należały do: Cieleckich, Męcińskich i Zborowskich, Stadnickich, Żabów oraz Konopków. Tytułowy księgozbiór Zbyszewskich i Iżyckich wchodził w skład biblioteki Konopków z Olesna.

Na temat księgozbioru Konopków z Brnia i Olesna pisała Edyta Więcek Natomiast brak w tej pracy informacji o kolekcji Zbyszewskich i Iżyckich, która trafiła do Olesna za sprawą małżeństwa młodszego syna barona Jana Franciszka Konopki h. Nowina - Jana Marii Leona, który w 1919 r. poślubił Marię Gabrielę Iżycką h. Bończa. E. Więcek w trakcie tworzenia swojej pracy nie dysponowała pełnym zasobem informacyjnym pozwalającym na scharakteryzowanie omawianej kolekcji w ramach księgozbioru Konopków. Niniejszy artykuł ma na celu uzupełnienie stanu badań o jej opis.

O rodach Zbyszewskich i Iżyckich nie wiadomo wiele. Informacje biograficzno-heraldyczne, zwłaszcza w przypadku Zbyszewskich, są szczątkowe i rozproszone. Niejednokrotnie informacje zawarte w różnych materiałach były z sobą sprzeczne lub niedokładne. Obie rodziny pochodzą z lubelskiego i na przełomie XVIII i XIX w. cieszyły się społecznym uznaniem, a w ich rękach znajdowały się znaczne dobra.

1 Mowa o pracy magisterskiej Księgozbiór rodziny Konopków z Brnia i Olesna w zbiorach Miejskiej Biblioteki Publicznej w Tarnowie, napisanej pod kierunkiem dr Ewy Wójcik i obronionej w lipcu 2013 r. w Instytucie Informacji Naukowej i Bibliotekoznawstwa na Uniwersytecie Pedagogicznym im. KEN w Krakowie. 


\section{Informacje biograficzne o rodzinie Zbyszewskich i Iżyckich}

Józef Zbyszewski h. Topór (1757-1820)² był rotmistrzem kawalerii polskiej oraz za panowania Stanisława Augusta Poniatowskiego zasiadał w Komisji Porządkowej Ziemi Chełmskiej ${ }^{3}$. Pełnił też urząd radnego Rady Powiatowej Powiatu Hrubieszowskiego $0^{4}$. Zbyszewski posiadał 13 dzieci, w tym braci Zygmunta i Grzegorza Zbyszewskich, których matką była Maria (Marianna) Szuszkowska 5 .

Zygmunt Zbyszewski (1786-1866) ${ }^{6}$, kasjer powiatowy, poślubił Apolonię Scholastykę Ratyńską h. Ślepowron7, córkę Adama Ratyńskiego 8 i Anny Targowskiej h. Rogala. Małżeństwo to było jednak krótkie, bowiem Apolonia rozwiodła się z Z. Zbyszewskim i w 1823 r. wyszła za Jana Łoskiego z Łosi h. Brodzic $^{9}$. Z. Zbyszewski odziedziczył po bracie Grzegorzu majątek Skhryhiczyn ${ }^{10}$, który posiadał do lat sześćdziesiątych XIX w., kiedy to z powodu zadłużenia w Towarzystwie Kredytowym Ziemskim ${ }^{11}$ został on zlicytowany i sprzedany ${ }^{12}$. Z. Zbyszewski najprawdopodobniej nie pozostawił po sobie potomstwa.

Grzegorz Ignacy Zbyszewski (1789-1856) ${ }^{13}$ był właścicielem Markuszowa, Kurowa, Olesina i innych posiadłości, asesorem wydziału Ministerstwa Przychodów i Skarbu Księstwa Warszawskiego ${ }^{14}$, a od 1846 r. - sędzią pokoju powiatu lubartowskiego ${ }^{15}$. Ponadto pełnił funkcję prezesa Dozoru Kościoła Parafialnego w Kurowie ${ }^{16}$, należał również do Towarzystwa Kredytowego Ziemskiego Guberni Lubelskiej, w którym w latach czterdziestych XIX w.

2 J. Zbyszewski zmarł w swoim majątku Skhryhiczyn - zob. G. Rąkowski, Polska egzotyczna, t. 2, Pruszków 2012, s. 204.

3 Zob. Dzienniki Ignacego Baranowskiego pisane w Lublinie przez rok 1815 i 1816, do dr. przygot., wstępem, przypisami i indeksami opatrzył B. Szyndler, Lublin 1995, s. 295.

4 Zob. tamże.

5 Zob. Baza indeksów ksiag metrykalnych i USC Lubelskich Korzeni, [online] <http:// regestry.lubgens.eu/viewpage.php?page_id $=766>(7.08 .2015)$.

6 Z. Zbyszewski urodził się w Skhryhiczynie, a zmarł w Hrubieszowie. Zob. tamże.

Zob. Dzienniki Ignacego Baranowskiego..., s. 112.

8 Zob. A. Kołodziejczyk, Józef Łoski (1827-1885) - zapomniany historyk, wydawca i rysownik, „Studia Podlaskie” 1993, t. 4, s. 101.

9 Zob. Apolonia Scholastyka Ratyńska h. Ślepowron, [online] <http://wielcy.pl/wgm/?m=N$\mathrm{G} \& \mathrm{t}=\mathrm{PN} \& \mathrm{n}=16.8 .115>(7.08 .2015)$.

10 Zob. G. Rąkowski, dz. cyt., s. 204.

11 Zob. I. Kowalska, I. Merżan, Rottenbergowie znad Buga, Warszawa 1989, s. 14-15.

12 Zob. [online] <http://www.sztetl.org.pl/pl/city/skryhiczyn/> (7.08.2015).

13 G.I. Zbyszewski zmarł w Kurowie i został pochowany w podziemiach kurowskiego kościoła - zob. Wdzięczne łzy i dotkliwe uczucie straty..., „Kurier Warszawski” 1857, nr 40, s. 210.

14 Zob. „Kalendarzyk Polityczny Pijarski...”[1814], s. 200.

15 „Sądownictwo w Królestwie Polskim...” [1853], s. 83.

16 Zob. K.A. Boreczek, Właściciele Kurowa i jego dóbr ziemskich, Lublin-Kurów 2005, s. $84-85$. 
zaciągnął pożyczkę, by podnieść z ruiny majątek $\mathrm{w}$ Kurowie ${ }^{17}$ po powstaniu listopadowym i przemarszu przez miasto wojska ${ }^{18}$. Wspierał finansowo kurowską szkołę ${ }^{19}$.

Grzegorz w 1815 r. poślubił w Kurowie ${ }^{20}$ Barbarę Moraczewską (1796-1850)21, córkę Wiktorii z Dłużewskich h. Pobóg Kuczyńskiej (1776-1826)22 i adwokata lubelskiego Szymona Moraczewskiego h. Cholewa (ok. 1770-?) ${ }^{23}$. Posiadali dwoje dzieci: Paulinę (1822-1892) i Wiktoryna (1816-1883).

W testamencie G.I. Zbyszewski zapisał na fundusz wieczysty dla klasztoru oo. Reformatorów w Kazimierzu wiatrak wraz z przyległymi gruntami oraz ogród owocowo-warzywny zwany „Xięzykowizną”24. Dwa lata po śmierci ojca dobra Markuszów przejął W. Zbyszewski (spłacając siostrę Paulinę sumą 27 tys. rubli w srebrze). Odziedziczony majątek był wtedy wart 153000 rubli (bez Piotrowic). Niestety W. Zbyszewski zbankrutował i ziemia wraz z zabudowaniami w 1871 r. została wystawiona na licytację. Dobra te nabył Wincenty Dobrzelewski ${ }^{25}$.

Paulina Wiktoria Rozalia Zbyszewska ${ }^{26}$ nigdy nie wyszła za mąż ${ }^{27}$, ale budziła podziw oraz zainteresowanie w środowisku inteligencji i arystokracji ze względu na swój talent muzyczny ${ }^{28}$, erudycję i feministyczne poglądy ${ }^{29}$. Była

17 Chodzi o zespół pałacowo-parkowy w Olesinie, który w tym czasie stanowił część Kurowa - zob. Olesin, [online] <http://pl.kurow.wikia.com/wiki/Olesin> (7.08.2015).

18 Również w tym ciężkim dla gminy Kurów czasie pomoc finansową zaoferował Wydział Skarbu Komisji Wojewódzkiej Lubelskiej - zob. K.A. Boreczek, dz. cyt., s. 83-84.

19 Zob. Historia szkoly Podstawowej im. Ks. G. Piramowicza w Kurowie, oprac. J. Michalik, [online] $<$ http://www.spkurow.pl/nowa/index.php?option=com_content\&view=category\&id=80\&Itemid=469> (7.08.2015).

20 Zob. Baza indeksów ksiag..., dz. cyt.

21 B. Zbyszewska zmarła w Kurowie i została pochowana w podziemiach tamtejszego kościoła. W jednej z naw kościoła zachowało się epitafium poświęcone jej osobie - zob. tamże.

22 Zob. $W$ dniu trzydziestym pierwszym..., „Gazeta Korespondenta Warszawskiego i Zagranicznego" 1826, nr 32, s. 336. Wiktoria rozwiodła się z S. Moraczewskim i wyszła za mąż za Antoniego Kajetana Kuczyńskiego h. Ślepowron (1755-1811), właściciela Kurowa - zob. L. Dembowski, Moje wspomnienia, t. 1, Petersburg 1898, s. 203.

23 Zob. Dzienniki Ignacego Baranowskiego..., s. 107.

24 Zob. Najjaśniejszy Pan..., „Kurier Warszawski” 1857, nr 67, s. 349.

25 Zob. Gmina Markuszów - Historia, [online] <http://www.markuszow.pl/pl,0,s137, historia. html> (7.08.2015).

26 Urodzona w Kurowie, zmarła w Warszawie, pochowana w grobie rodzinnym na Cmentarzu Powązkowskim - zob. Ś.p. Paulina Zbyszewska, ,Kurier Warszawski” 1892, nr 242, s. 4; Baza indeksów ksiag..., dz. cyt.

27 Zob. M. Berkan-Jabłońska, Korespondencyjne spotkania Gabrieli z Güntherów Puzyniny i Katarzyny z Lipińskich Lewockiej, „Tematy i Konteksty” 2012, nr 2 (7), s. 84.

28 Nauczycielem muzyki P.W.R. Zbyszewskiej do 1838 r. był Czech Wacław Prochazka (1808-1884) - zob. Wacław Prochazka (wspomnienie pośmiertne), „Kłosy” 1884, nr 990, s. 397-398.

29 Maria Sulicka charakteryzowała P.W.R. Zbyszewską też jako osobę ekscentryczną, poróżnioną z całą rodziną - zob. M. Stępień, Narcyza Żmichowska, Warszawa 1968, s. 289. 
miłośniczką książek ${ }^{30}$. Tadeusz Boy-Żeleński pisał o córce B. i G.I. Zbyszewskich:

Znała całą Europę, słuchała w Paryżu wykładów Micheleta, w Berlinie Hegla. Mówiła płynnie kilkoma językami. Rozprawiała o ekonomi politycznej równie biegle jak o sztuce; nie mniej dobrze znała matematykę, nauki przyrodnicze itd. ${ }^{31}$

Natomiast Julian Bartoszewicz w swych wspomnieniach opisuje niezwykły talent krasomówczy P.W.R. Zbyszewskiej ${ }^{32}$. Pisała też ona wiersze ${ }^{33}$ i próbowała komponować utwory muzyczne ${ }^{34}$.

W latach 1839-1842 odbyła podróż po Włoszech, w czasie której poznała Walerego Wielogłowskiego (1805-1865) - zaszczepił on P.W.R. Zbyszewskiej ducha demokracji ${ }^{35}$. W 1857 r. po śmierci rodziców odbyła podróż do Paryża ${ }^{36}$, z której powróciła w 1860 r. ${ }^{37}$ Kobieta zasłynęła nie tylko jako przyjaciółka poetki Narcyzy Żmichowskiej ${ }^{38}$, z którą należały do tzw. „entuzjastek” ${ }^{39}$, lecz także z działań na rzecz ruchu ludowo-demokratycznego, w efekcie czego wraz ze Żmichowską została uwięziona w klasztorze karmelitanek w Lublinie ${ }^{40}$. W 1849 r. P.W.R. Zbyszewską uwolniono dzięki wstawiennictwu byłego marszałka szlachty lubelskiej Jana hr. Jezierskiego ${ }^{41}$.

30 Wraz z innymi entuzjastami wypożyczała m.in. książki z Biblioteki Szkoły Głównej zob. H. Kozerska, Warszawska Biblioteka Uniwersytecka (1832-1871): Biblioteka Rządowa Okręgu Naukowego: Główna, Warszawa 1967, s. 88. Jako zamiłowaną czytelniczkę wspomina P.W.R. Zbyszewską sama N. Żmichowska - zob. M. Stępień, dz. cyt., s. 156.

31 T. Boy-Żeleński, Ludzie żywi, Kraków 1975, s. 145.

32 Zob. J. Bartoszewicz, Z notatnika pamiętniczego Juliana Bartoszewicza, cz. 2: Od wydawcy, „Przegląd Historyczny” 1912, t. 14, nr 3, s. 398-399.

33 W zbiorach rękopisów Biblioteki Jagiellońskiej zachował się jej wiersz z 1865 r. napisany dla Józefa Ignacego Kraszewskiego - zob. Korespondencja Józefa Ignacego Kraszewskiego, seria III: Listy z lat 1863-1887, t. 85, [w:] Inwentarz rękopisów Biblioteki Jagiellońskiej, cz. 1: Nr 6001-7000, cz. 2: Nr 6501-7000, oprac. A. Jałbrzykowska, J. Zathey, Kraków 1963, s. 65.

34 Zob. T. Boy-Żeleński, dz. cyt., s. 145.

35 A. Kraushar, Kartka z życia Narcyzy Żmichowskiej (1844-1850), Warszawa 1909, s. 9.

36 Zob. Przyjechali do Warszawy, „Kurier Warszawski” 1857, nr 101, s. 530.

37 Zob. Przyjechali do Warszawy, „Kurier Warszawski” 1860, nr 48, s. 258.

38 T. Boy-Żeleński (dz. cyt., s. 145) dopatrywał się w tej znajomości miłości homoseksualnej.

39 W ramach działalności tej grupy P.W.R. Zbyszewska zgłosiła Henrykowi Krajewskiemu zamiar dokonania zamachu na cara Mikołaja I podczas jego pobytu w Warszawie w 1848 r. - zob. Literackie przystanki nad Warta, pod. red. Z. Szweykowskiego, Poznań 1962, s. 14.

40 Powodem uwięzienia obu kobiet była przejęta przez władze ich korespondencja z $1844 \mathrm{r}$., którą powiązano z działalnością Towarzystwa Demokratycznego Polskiego - zob. Wiek XIX. Sto lat myśli polskiej: życiorysy, streszczenia, wyjątki, pod. red. B. Chlebowskiego i in., t. 9: Wykaz życiorysów $i$ wypisów, Warszawa [1924?], s. 73.

${ }^{41}$ N. Żmichowską uwolniono dopiero w 1855 r. Pisarka zerwała po tym przyjaźń z P.W.R. Zbyszewską - zob. Wiek XIX. Sto lat..., s. 73. 
P.W.R. Zbyszewska należała do Towarzystwa Zachęty Sztuk Pięknych w Warszawie ${ }^{42}$. W ramach członkostwa w Lubelskim Towarzystwie Dobroczynności udzielała się jako opiekunka w Zakładzie Sierot ${ }^{43}$. Była też hojną filantropką. Nekrolog z 1892 r. w „Biesiadzie Literackiej” opisuje ją jako panią miłosierną, która ufundowała ubogim dzieciom ochronkę ${ }^{44}$ oraz przekazała w testamencie 15000 rub. na jej utrzymanie, a także - 10000 rub. na szkołę rzemiosł i 15000 rub. na Kasę im. Mianowskiego ${ }^{45}$.

Wiktoryn Zbyszewski (1816-1883) ${ }^{46}$, dziedzic Markuszowa ${ }^{47}$, był członkiem Resursy Kupieckiej ${ }^{48}$ oraz Towarzystwa Rolniczego w Królestwie Polskim $^{49}$, jednak bardziej zasłynął z zamiłowania do gonitw konnych ${ }^{50}$, które przyczyniły się do jego bankructwa i utraty odziedziczonego Markuszowa. W 1852 r. poślubił w Warszawie Bronisławę Marię Olechowską (1825-1865) ${ }^{51}$, córkę Pawła i Bibiany Olechowskich ${ }^{52}$. Posiadali jedną córkę ${ }^{53}$. B.M. Zbyszewska należała do Lubelskiego Towarzystwa Dobroczynności ${ }^{54}$, a także słynęła w Lubelskiem jako znakomity hodowca kur, które prezentowała na wystawach w Lublinie ${ }^{55}$. Ponadto zajmowała się kompozytorstwem (wydała osiem

42 Zob. Losowanie obrazów w Towarzystwie Zachęty Sztuk Pięknych, „Kurier Warszawski” 1879 , nr 291, s. 2-3.

43 Zob. Zdanie sprawy z działań Lubelskiego Towarzystwa Dobroczynności za rok 1863 w Lublinie, Lublin [1864], s. 18.

44 Była to Ochronka nr $27 \mathrm{im}$. Zbyszewskich przy ul. Kruczej - zob. Z miasta..., „Kurier Warszawski" 1907, nr 252, s. 2.

45 Zob. Ś.P. Paulina Zbyszewska, „Biesiada Literacka” 1892, nr 41, s. 235.

46 W. Zbyszewski został pochowany w Czerwińsku nad Wisłą - zob. Wiktoryn Zbyszewski, [online] <http://billiongraves.com/record/WIKTORYN-ZBYSZEWSKI/9175511\#given_names= WIKTORYN\&family names=ZBYSZEWSKI $>(7.08 .2015)$.

47 Zob. Nekrologia, „Gazeta Warszawska” 1883, nr 271, s. 4.

48 Zob. Na odbytem wczoraj..., „Kurier Warszawski” 1854, nr 291, s. 1475.

49 Zob. Lista członków Towarzystwa Rolniczego w Królestwie Polskim w roku 1861, [b.m., b.r.], s. 69 .

50 Zob. np. Dyrekcja Wyścigów Konnych..., „Gazeta Warszawska” 1857, nr 186, s. 1.

51 Zob. Geneteka - Baza Polskiego Towarzystwa Genealogicznego, [online] <http:// geneteka.genealodzy.pl/index.php?rid $=S \&$ from_date $=\&$ to_date $=\&$ search_lastname $=$ zbyszewski\&search_astname $2=\& \operatorname{exac}=1 \& \mathrm{rpp} 1=0 \& \mathrm{bdm}=\mathrm{S} \& \mathrm{w}=71 \mathrm{wa} \& \mathrm{op}=\mathrm{gt} \&$ lang $=$ pol $>$ (7.08.2015); Słownik Muzyków Polskich Dawnych i Nowoczesnych..., przez A. Sowińskiego, Paryż 1874 , s. 427-428. B.M. Olechowska pochowana została na cmentarzu parafialnym rzymskokatolickim w Lublinie - zob. S.O. [S. Ostrołęcki], Cmentarz parafialny rzymsko-katolicki w Lublinie, Warszawa 1902, s. 38.

52 Zob. Geneteka-Baza Polskiego Towarzystwa Genealogicznego, [online] <http://geneteka. genealodzy.pl/index.php?rid=S\&from_date $=\&$ to_date $=\&$ search_lastname $=$ zbyszewski\&search lastname $2=\&$ exac $=1 \& \mathrm{rpp} 1=0 \& \mathrm{bdm}=\overline{\mathrm{S} \& \mathrm{w}}=71 \mathrm{wa} \& \mathrm{op}=\mathrm{gt} \&$ lang $=\overline{\mathrm{pol}}>(7.08 .2015)$.

53 Niestety nie są znane jej personalia, wiadomo jedynie, że wyszła za mąż - zob. Nekrologia, „Gazeta Warszawska” 1883, nr 271, s. 4.

${ }_{54}$ Zob. Zdanie sprawy z działań Lubelskiego Towarzystwa Dobroczynności za rok 1857 $w$ Lublinie, Lublin [1858], s. 14.

${ }_{55}$ Zob. Wystawa rolnicza w Lublinie, „Czytelnia Niedzielna” 1860, nr 42, s. 354. 
utworów muzycznych ${ }^{56}$ ) oraz pisarstwem (w 1857 r. ukazała się w Warszawie u Gustawa Leona Glücksberga jej powieść dla dzieci pt. Nauka i rozrywka, napisana pod męskim pseudonimem: Paweł Ratuld ${ }^{57}$ ). Również pod inicjałami P.R. pisywała wiele artykułów ${ }^{58}$. W latach 1847-1848 współpracowała z „Przeglądem Naukowym”, gdzie publikowała szkice literackie pt. Bazgranina eksautorki oraz rozprawy o emancypacji kobiet - podpisywała się jako Bronisława lub B.O. ${ }^{59} \mathrm{Na}$ starość próbowała rycia $\mathrm{W}$ drewnie ${ }^{60}$. B.M. Zbyszewska obracała się w środowisku artystycznym ${ }^{61}$. W 1858 r. podczas pobytu w Paryżu odwiedziła Cypriana Kamila Norwida ${ }^{62}$. Poeta następnie dedykował swojemu gościowi jeden z wierszy - liryk Pani Bronisławie Zbyszewskiej63.

Karolina Moraczewska (ok. 1790-?), siostra B. Zbyszewskiej z Moraczewskich, poślubiła ok. 1810 r. Józefa Iżyckiego h. Bończa (1787-1865) ${ }^{64}$, dzierżawcę Koniuchów i Dubienki, z którym miała pięcioro dzieci' ${ }^{65}$. Do $1875 \mathrm{r}$. byli oni właścicielami dóbr strzeleckich, w skład których wchodziły Maziarnia Strzelecka i Strzelce, oraz posiadali dobra Paluchów i Wielkie ${ }^{66}$. W 1819 r. J. Iżycki odkupił od swojego brata Antoniego Ługową ${ }^{67}$, a po śmierci B. i G. Zbyszewskich K. i J. Iżyccy stali się spadkobiercami dóbr kurowskich (P. Zbyszewska w tym czasie podróżowała po Europie ${ }^{68}$, a następnie przenio-

56 Zob. W dniu..., „Kurier Warszawski” 1865, nr 179, s. 937.

57 Obecnie wiadomo tylko o dwóch zachowanych egzemplarzach - dostępnych w Bibliotece Narodowej i Bibliotece Uniwersytetu Mikołaja Kopernika w Toruniu.

58 Zob. Ś.p. Bronisława Zbyszewska, „Gazeta Polska” 1865, nr 178, s. 1.

59 Publikacje B. Zbyszewskiej w „Przeglądzie Naukowym” mogłyby wskazywać na przynależność do grupy „entuzjastek” N. Żmichowskiej - zob. J. Rudnicka, Nieznane autografy Cypriana Norwida, „Twórczość” 1960, nr 4, s. 92-93. Piotr Chmielowski w swoim opracowaniu wskazuje błędnie na Julię Janiszewską, która miałaby publikować pod pseudonimem „Bronisława” - zob. P. Chmielowski, Autorki polskie wieku XIX, Warszawa [ok. 1880], s. 264.

60 Zob. Ś.p. Bronisława Zbyszewska.., s. 1.

61 Zob. jak wyżej.

62 Zob. Z. Sudolski, Norwid. Opowieść biograficzna, Warszawa 2003, s. 296.

63 Zob. J. Rudnicka, Nieznane autografy Cypriana..., s. 94.

64 Zob. Józef Iżycki, „Kurier Warszawski” 1865, nr 295, s. 1530.

65 Pozostałe dzieci Józefa i Karoliny Iżyckich to: Marianna (1818-?), Felicja (1819-1888), żona księcia Jeremiasza Józefa Woronieckiego h. Korybut (1804-1877), Henryk (1820-?), żonaty z Adelą Kossowicz h. Wieniawa (1848-?), i Apolonia (1836-?), żona Dominika Rzewuskiego (1825$1895)$ - zob. A. Boniecki, Herbarz polski, cz. 1: Wiadomości historyczno-genealogiczne o rodach szlacheckich, t. 8, Warszawa 1986, s. 92.

66 Zob.Ziemiaństwo na Lubelszczyźnie-majątek Strzelce, [online] < http://teatrnn.pl/leksykon/ node/4550/ziemia\%C5\%84stwo_na_lubelszczy $\%$ C5\%BAnie_\%E2\%80\%93_maj\%C4\%85tek strzelce> (7.08.2015).

${ }_{67}$ Zob. Eugów - Wikipedia, [online] <https://pl.wikipedia.org/wiki/\%C5\%81ug\%C3\%B3w_ (wojew\%C3\%B3dztwo_lubelskie) $>$ (7.08.2015).

68 Wróciła z Paryża w 1860 r. - zob. Przyjechali do Warszawy, „Kurier Warszawski” 1860, nr 48, s. 258. 
sła się do Warszawy na ul. Mazowiecką $5^{69}$ ), które pozostały w ich rękach do $1865 \mathrm{r}^{70} \mathrm{~J}$. Iżycki był sędzią pokoju powiatu siedleckiego ${ }^{71}$, radcą Rady Obywatelskiej i prezesem Towarzystwa Kredytowego Ziemskiego Województwa Lubelskiego $^{72}$, członkiem Towarzystwa Rolniczego w Królestwie Polskim ${ }^{73}$ oraz radnym w Radzie Powiatowej Powiatu Lubartowskiego ${ }^{74}$.

Ich syn Józef (1822-1893) ${ }^{75}$ poślubił w 1853 r. w Porycku Olgę Karolinę Czacką z Czacza h. Świnka (1830-1889) ${ }^{76}$, córkę hr. Wiktora Grzegorza Kazimierza Czackiego (1801-1853) ${ }^{77}$ i Pelagii ks. Sapieha h. Lis (1809-1892) ${ }^{78}$. Mieli dwóch synów i trzy córki ${ }^{79}$.

J. i O. Iżyccy posiadali w latach 1849-1858 Krześlin ${ }^{80}$. O. Iżycka udzielała się jako opiekunka w Zakładzie Sierot Lubelskiego Towarzystwa Dobroczynności, gdzie działała też P. Zbyszewska ${ }^{81}$. Józef był natomiast członkiem Towarzystwa Rolniczego w Królestwie Polskim ${ }^{82}$ oraz sędzią pokoju powiatu siedleckiego ${ }^{83}$, a następnie - sędzią w Kazimierzu ${ }^{84}$. Należał też do Towarzystwa Resursy Kupieckiej ${ }^{85}$ i był radnym Rady Powiatowej Powiatu Lubelskiego ${ }^{86}$.

69 Zob. W. Dzierżanowski, Przewodnik warszawski informacyjno-adresowy na rok $1870 \ldots$, Warszawa [1870], s. 425.

70 Zob. K.A. Boreczek, dz. cyt., s. 87.

71 Zob. Wiadomości Warszawskie, „Gazeta Polska” 1830, nr 1, s. 2.

72 Zob. Dyrekcja szczegółowa Towarzystwa Kredytowego Ziemskiego, „Dziennik Województwa Lubelskiego" 1834, nr 22, dod. III, s. 470.

73 Zob. Lista członków Towarzystwa Rolniczego..., s. 69.

74 Zob. Rozmaitości, „Powszechny Dziennik Krajowy” 1830, nr 47, s. 242.

75 J. Iżycki urodził się w Koniuchach, a zmarł w Warszawie, gdzie został pochowany w grobie rodzinnym na Cmentarzu Powązkowskim - zob. Ś.P. Józef Iżycki, „Kurier Warszawski” 1893, nr 311, s. 5.

76 Pochowana w grobie rodzinnym na Powązkach w Warszawie - zob. Nekrolog Olgi z hrabiów Czackich Iżyckiej, „Kurier Warszawski” 1889, nr 24, s. 4.

77 Zob. A. Boniecki, Herbarz polski..., t. 3, Warszawa 1986, s. 246.

78 Zob. jak wyżej.

79 Pozostałe dzieci J. i O. Iżyckich to: Pelagia Marianna Ewa (1857-1930), żona hrabiego Józefa Łukasza Wielhorskiego h. Kierdeja (1821-1892), Maria (1860-?), żona Alfreda Czarnomskiego h. Ślepowron (1860-1897), Karolina Maria Franciszka (1860-?), żona Aleksandra Mariana Walewskiego h. Pierzchała (1860-?), i Władysław (1861-?), żonaty z Ireną Rzewuską (1870-?) - zob. Józef Iżycki h. Bończa, [online] <http://wielcy.pl/wgm/?m=NG\&t=PN\&n=8.179.214> (7.08.2015)

80 Zob. A. Bereza, W. Okniński, Sądownictwo siedleckie. Tradycje i współczesność, Warszawa 2010, s. 54.

81 Zob. Zdanie sprawy z działań Lubelskiego Towarzystwa Dobroczynności za rok 1863..., s. 18.

82 Zob. Lista członków Towarzystwa Rolniczego..., s. 70.

83 Zob. Rozkaz do Zarządu Cywilnego Królestwa Polskiego, „Gazeta Warszawska” 1849, nr 259, s. 1.

${ }^{84}$ Zob. Przez postanowienie Warszawskiego Jenerat-Gubernatora..., „Kurier Warszawski” 1875 , nr 125 , s. 1 .

85 Zob. Na wczorajszem ballotowaniu Kandydatów..., „Kurier Warszawski” 1855, nr 313, s. 1593.

86 Zob. Wypadek wyborów..., „Kurier Warszawski” 1861, nr 250, s. 1277. 
Syn Iżyckich Józef ${ }^{87}$ (1854-1909) poślubił w 1888 r. $^{88}$ Leonię Dachowską z Dachowa h. Łodzia (1862-1929) ${ }^{89}$, córkę Kazimierza Dachowskiego (1822-1894) i Zofii Zbyszewskiej h. Topór (ur. ok. 1830-?) ${ }^{90}$.

Córka K. i Z. Dachowskich otrzymała staranne wykształcenie w zakładzie Zgromadzenia Sióstr Niepokalanego Poczęcia NMP w Jazłow$\mathrm{cu}^{91}$. Leonia była członkiem zarządu Towarzystwa Gniazd Sierocych ${ }^{92}$, przewodniczącą Domu Wychowania dla dzieci inteligencji prowadzonego przez Komitet Obywatelski m. Warszawy ${ }^{93}$, opiekunką w ochronce ufundowanej przez P. Zbyszewską ${ }^{94}$, zasiadała też w prezydium Sekcji Tanich Kuchen Zarządu Miejskiego Warszawy ${ }^{95}$ oraz - jako członek zwyczajny - należała do Towarzystwa Miłośników Historii w Warszawie ${ }^{96}$. Wraz z mężem byli członkami Warszawskiego Towarzystwa Dobroczynności ${ }^{97} \mathrm{i}$ Towarzystwa św. Wincentego à Paulo ${ }^{98}$. Józef zasiadał w komisji rewizyjnej Towarzystwa Wyścigów Konnych i Wystawy Zwierząt Gospodarskich w Królestwie Polskim ${ }^{99}$ oraz w Warszawskiej Radzie Rolniczej ${ }^{100}$, a także sędziował w wyścigach konnych ${ }^{101}$. Ponadto należał do Towarzystwa Zachęty Sztuk Pięknych ${ }^{102}$, Warszawskiego Towarzystwa

${ }^{87} \mathrm{~W}$ parku dworskim w Olesinie znajduje się figura upamiętniająca narodziny braci Wiktora i Józefa Iżyckich w 1854 r. W czasie jej powstania Olesin należał do Zbyszewskich, a Iżyccy byli częstymi gośćmi w tych dobrach - zob. K.A. Boreczek, dz. cyt., s. 86. J. Iżycki urodził się w Porycku na Wołyniu w majątku swego dziadka Wiktora Czackiego. Zmarł w Zatorach, gdzie został pochowany na cmentarzu parafialnym - zob. Nekrolog ś.p. Józef Izycki, „Słowo” 1909, nr 284, s. 6. Wydawnictwa genealogiczne jednak nie wspominają o narodzinach brata (być może bliźniaka?) J. Iżyckiego.

88 Informacja na podstawie zachowanych telegramów z 1888 r. z życzeniami dla nowożeńców - Zbiór 22 telegramów z kolekcji Iżyckich i Zbyszewskich. MBP w Tarnowie. Rękopisy: syg. od 32 do 53.

89 Leonia urodziła się w Leśkowej, a zmarła w Szczawnicy. Pochowana została w Oleśnie koło Dąbrowy Tarnowskiej w grobowcu rodzinnym Konopków - zob. Nekrolog Leonii z Dachowskich Józefowej Iżyckiej, „Kurier Warszawski” 1929, nr 246, s. 22.

90 Zob. A. Boniecki, Herbarz polski..., t. 4, Warszawa 1986, s. 56.

${ }_{91}$ Zob. Spis uczennic Zaktadu SS. Niepokalanego Poczęcia N.M.P w Jazłowcu, [online] $<$ http://www.lenczewski.com.pl/uczennice.html> (7.08.2015).

92 Zob. Towarzystwo Gniazd Sierocych, „Nowa Gazeta” 1916, nr 500a, Dodatek Nadzwyczajny, s. 2 .

93 Zob. Spis instytucyj K.O. m. Warszawy, „Dziennik Komitetu Obywatelskiego Miasta Warszawy" 1915 , nr 15, s. 2.

94 Zob. Wizyty, „Kurier Warszawski” 1897, nr 136, s. 1.

95 Zob. Zarząd miasta stolecznego Warszawy, „Okólnik”, 26.07.1916, nr 45, s. 6.

96 Zob. Sprawozdanie za 1914 r. Towarzystwa Miłośników Historyi w Warszawie, [Warszawa] 1915, s. 12.

97 Zob. Warszawskie Towarzystwo Dobroczynności, „Kurier Warszawski” 1903, nr 105, s. 11.

98 Zob. Św. Wincenty a Paulo, „Kurier Warszawski” 1895, nr 70, s. 3.

99 Zob. Towarzystwo Wyścigów Konnych, „Słowo” 1909, nr 127, s. 2.

100 Zob. Warszawska Rada Rolnicza, „Gazeta Handlowa” 1903, nr 32, s. 1.

101 Zob. Wyścigi pod Pultuskiem, „Świat” 1909, nr 31, s. 19.

102 Zob. Sprawozdanie komitetu Towarzystwa Zachęty Sztuk Pięknych w Królestwie Polskim za 1902 rok, Warszawa 1903. 
Pomocy Lekarskiej i Opieki nad Psychicznie i Nerwowo Chorym ${ }^{103}$ i Towarzystwa Wzajemnych Ubezpieczeń od Gradobicia „Ceres”104. Prezesował pułtuskiemu Kołu Sportowemu ${ }^{105}$. W 1905 r. J. Iżycki otworzył ochronkę dla dzieci w Zatorach ${ }^{106}$. W swoim majątku prowadził cegielnię i gorzelnię oraz młyn parowy ${ }^{107}$. Małżeństwo dochowało się czterech córek: Heleny Marii (1890-1893), Marii Gabrieli (1897-1985), Leonii (1899-1900) oraz Pelagii (1900-?)

Maria Gabriela w 1919 r. poślubiła w Warszawie Jana Marię Leona h. Nowina (1889-1980) z Brnia koło Dąbrowy Tarnowskiej, syna barona Jana Franciszka Stanisława Konopki (1855-1948) i hrabiny Anny Krystyny Leontyny Bobrowskiej h. Boleścic (1856-1924) ${ }^{109}$. Maria była feministką ${ }^{110}$. Razem z Janem mieli dwoje dzieci ${ }^{111}$. J. Konopka $\mathrm{z}$ wykształcenia był inżynierem agronomem $^{112}$. W latach 1914-1919 służył w wojsku austriackim, a następnie polskim - do 1921 r. ${ }^{113}$ Pełnił funkcję prezesa Okręgowego Towarzystwa Rolniczego w Dąbrowie Tarnowskiej ${ }^{114}$ i Wojewódzkiego Związku Ziemian w Krakowie ${ }^{115}$. W 1935 r. został mianowany radcą Izby Rolnej w Krakowie, a rok później wybrano go na wiceprezesa Rady Nadzorczej Towarzystwa Kredytowego Ziemskiego we Lwowie. Pisał o agronomii na łamach periodyków rolni$\mathrm{czych}^{116}$. Sprawnie zarządzał swoim majątkiem, założył w Oleśnie gorzelnię, która przynosiła znaczne dochody ${ }^{117}$.

${ }^{103}$ Zob. Z Towarzystwa Opieki nad Umystowo Chorymi, „Wiek” 1903, nr 90, s. 6.

104 Zob. „Ceres”, „Kurier Warszawski” 1902, nr 14, s. 9-10.

105 Zob. Igrzyska sportowe, „Głos Warszawski” 1908, nr 161, s. 2.

106 Zob. Nowe ochronki, „Kurier Warszawski” 1905, nr 283, s. 4.

107 Zob. „Rocznik Adresowy Królestwa Polskiego...” 1902, s. 646C-648C.

108 Pelagia w 1913 r. poślubiła Teodora Libiszowskiego właściciela dóbr Sosnowica w powiecie włodawskim - zob. Zaślubiny, „Kurier Warszawski” 1913, nr 152, s. 2; Z kroniki towarzyskiej, „Świat” 1913, nr 25, s. 28.

${ }_{109}$ Zob. A. Boniecki, Herbarz polski..., t. 11, Warszawa 1987, s. 98.

110 Zob. Z dni jubileuszowych Pauliny Kuczalskiej-Reinschmit d. 6 i 7 maja 1911 r., Warszawa 1911, s. 10.

${ }_{111}$ Dzieci Konopków: Jan Feliks (1920-2006), żonaty z Magdaleną Mehoffer h. własnego (1925- ), oraz Anna Maria (1924- ), zamężna z Zbigniewem Dobrskim h. Jastrzębiec (1918-1971) - zob. Jan Maria Leon bar. Konopka h. Nowina, [online] <http://wielcy.pl/ $\mathrm{wgm} /$ ?m=NG\&t=PN\&n=11.96.391> (7.08.2015).

112 Zob. Corpus studiosorum Universitatis Iagellonicae 1850/51-1917/18: K-E, pod red. K. Stopki, Kraków 2009, s. 373.

113 Zob. Jan Leon Konopka, [w:] Czy wiesz kto to jest?, pod red. S. Łozy, Warszawa 1938, s. 358.

${ }^{114}$ Zob. jak wyżej.

115 Zob. Jeszcze o Zebraniu Ziemian w Krakowie, „Głos Narodu” 1933, nr 140, s. 7.

116 Zob. Jan Leon Konopka, [w:] Czy wiesz kto..., s. 358.

117 Zob. Dąbrowa Tarnowska. Zarys dziejów miasta i powiatu, pod red. F. Kiryka, Z. Ruty, Warszawa-Kraków 1974, s. 509. 


\section{Losy kolekcji oraz jej charakterystyka}

Niewiele można powiedzieć o drodze księgozbiorów Zbyszewskich i Iżyckich z Lubelszczyzny i Mazowsza do dworu Konopków w Oleśnie, a następnie, po upaństwowieniu majątku Konopków, do MBP w Tarnowie ${ }^{118}$. $\mathrm{Z}$ akt kancelarii lubelskiego notariusza Stefana Konwickiego ${ }^{119}$ wiemy o inwentarzu rzeczy wspólnych po B. i G. Zbyszewskich, który został spisany po śmierci Grzegorza w 1856 r. Z wykazu wynika, że po śmierci Barbary jej księgozbiór został podzielony pomiędzy spadkobierców. Brak danych o jego wielkości, ale zapis dotyczący wartości (260 rubli i 73 kopiejki) sugeruje, iż była to jedna $\mathrm{z}$ większych kolekcji bądź też szczególnie starannie oprawiona ${ }^{120}$. Natomiast Grzegorz posiadał 71 tytułów (w tym 51 powieści ${ }^{121}$ ) o wartości 59 rubli i 70 kopiejek. Były to pozycje wydane w ciągu ostatnich pięciu lat poprzedzających śmierć właściciela ${ }^{122}$. W księgozbiorze G. Zbyszewskiego tytuły prac naukowych stanowiły niespełna $17 \%{ }^{123}$. Charakter kolekcji można częściowo odtworzyć również na podstawie list prenumeratorów i subskrybentów, które były publikowane w czasopismach i książkach wydawanych w XIX w. I tak wiadomo np. o zakupie przez P. Zbyszewską aż 15 egzemplarzy drugiego wydania trzytomowej Historii naturalnej zastosowanej do potrzeb życia praktycznego i do rzeczy krajowych Wojciecha Bogumiła Jastrzębowskiego ${ }^{124}$ i jednego egzemplarza Wzorów sztuki średniowiecznej $w$ dawnej Polsce ${ }^{125}$. Z tego źródła dowiadujemy się też, że G.I. Zbyszewski nabył sześć egzemplarzy Snopka Nadwiślańskiego ${ }^{126}$, Z. Zbyszewski oraz J. Iżycki kupili po jednym egzemplarzu Rzek Polskich ${ }^{127}$,

${ }^{118}$ Majątek ruchomy po nacjonalizacji posiadłości zabezpieczyli przedstawiciele Muzeum Ziemi Tarnowskiej, ponownie powołanego do życia w 1945 r. Książki następnie zostały przekazane do MBP im. J. Słowackiego w Tarnowie. Biblioteka ta straciła w czasie II wojny światowej ok. 45\% swojego księgozbioru - zob. Z dziejów Miejskiej Biblioteki Publicznej im. J. Słowackiego w Tarnowie 1908-1968, pod red. B. Jaśkiewicza, Tarnów [1970], s. 59, 90.

119 AP w Lublinie. Akta notarialne S. Konwickiego 1856 r., akt 23, Inwentarz rzeczy wspólnych po Barbarze i Grzegorzu Zbyszewskich.

${ }^{120}$ Zob. jak wyżej.

${ }^{121} \mathrm{~Np}$. dwa tomy powieści zebranych Zygmunta Kaczkowskiego należących do cyklu Ostatni z Nieczujów (Petersburg 1853 i 1855) - zob. jak wyżej.

122 Zob. jak wyżej.

${ }^{123}$ Zob. jak wyżej.

${ }^{124}$ Zob. A. Dymel, Prenumeratorzy piśmiennictwa naukowego wydanego w Królestwie Polskim w pierwszej polowie XIX wieku, Lublin 1992, s. 146.

125 Wzory sztuki średniowiecznej i z epoki odrodzenia po koniec wieku XVII w dawnej Polsce, Seria II, wyd. przez A. Przezdzieckiego i E. Rastawieckiego, Warszawa 1855-1858.

${ }^{126}$ Również P. Zbyszewska zakupiła to wydanie. Snopek Nadwiślański z płodów piśmiennictwa krajowego, zebrali M. Ossoryja i Karol B. z Jarosławca; z muzyką J. Elsnera i J.F. Dobrzyńskiego; drzeworytami W. Smokowskiego, Warszawa 1844, s. 266.

${ }^{127}$ K. Jaxa-Marcinkowski, Rzeki Polskie: poema, pomniki stawy narodowej opiewajace napisane, Warszawa 1826, s. 92, 95. 
a ten ostatni zaopatrzył się ponadto w jeden egzemplarz pracy $O$ potrzebie i możności zaprowadzenia w naszym kraju jedwabnictwa ${ }^{128}$.

Najprawdopodobniej po śmierci Grzegorza jego księgozbiór został podzielony pomiędzy Paulinę i Wiktoryna ${ }^{129}$. Również majątek ruchomy (w tym książki) po bracie Grzegorza musiał zostać rozdysponowany pomiędzy jego dzieci i stąd książki z podpisem Z. Zbyszewskiego znalazłyby się w kolekcji P. Zbyszewskiej. Następnie bezdzietna Paulina zapisała swój majątek Leonii z Dachowskich Iżyckiej, żonie syna jej kuzyna J. Iżyckiego ${ }^{130}$. Córka L. Iżyckiej wniosła w posagu J.M. Konopce znaczną kolekcję książek, wśród których znalazły się woluminy należące nie tylko do jej rodziców, lecz także do rodziny Czackich oraz Zbyszewskich. Na podstawie materiałów archiwalnych i badań proweniencyjnych nad zachowaną kolekcją nie można też określić, czy księgozbiór, który został przejęty z dworu Konopków w Oleśnie, był kolekcją o charakterze bibliofilskim, na co mogłaby wskazywać jej liczebnośśćl ${ }^{131}$. W zbiorze tym brak bowiem specjalnie zaprojektowanych ekslibrisów, wytwornych opraw tworzonych na zamówienie, pięknych edytorsko wydań czy dużej ilości bardzo rzadkich wydawnictw. Życiorysy członków rodzin Zbyszewskich i Iżyckich również nie wskazują na bibliofilskie zainteresowanie książkami, a raczej - na przykładanie wagi do ich aspektu użytkowego. Książki stanowiły bowiem dla obu rodów źródło rozrywki i pozyskiwania wiedzy związanej z prywatnymi zainteresowaniami poszczególnych właścicieli.

Brak też informacji na temat sposobu przechowywania zbiorów, która mogłaby potwierdzić bibliofilskie zainteresowania właścicieli księgozbioru. W opracowaniach na temat dworów w Markuszowie, Olesinie, Zatorach czy innych posiadłościach należących do Zbyszewskich i Iżyckich nie uwzględniono informacji o istnieniu oddzielnych pomieszczeń bibliotecznych. Wiadomo za to, że w dworze Konopków regały z książkami stały w największym pomieszczeniu, które mieściło salon i jadalnię ${ }^{132}$. Według protokołu zdawczo-

128 J.N. Kurowski, O potrzebie i możności zaprowadzenia w naszym kraju jedwabnictwa oraz Krótka nauka hodowania jedwabnic $i$ drzewa morwowego z najnowszych zagranicznych dziet, cz. 1-3, Warszawa 1836, Wykaz pp. prenumeratorów, s. [5].

${ }^{129}$ Z listów N. Żmichowskiej wiadomo o sporze o spadek Pauliny z krewną Bronisławą (zapewne chodzi o żonę Wiktoryna) - zob. N. Żmichowska, Listy, t. 2: Rozdroża, pod red. S. Pigonia; do dr. przygot. i komentarzem opatrzyła M. Romankówna, Wrocław 1957, s. 579.

130 Zob. Testament, „Gazeta Polska” 1892, nr 198, s. 2; Sprawa o zapis na rzecz szkoty rzemiost, „Gazeta Polska” 1895, nr 253, s. 2.

${ }_{131}$ Wiadomo tylko, że P. Zbyszewska była niezwykłą miłośniczką książek - zob. M. Stępień, dz. cyt., s. 156. Natomiast L. Iżycka zbierała porcelanę korecką i baranowiecką oraz majolikę nieborowską - zob. A. Szkurłat, Kolekcjonerstwo ceramiki w Polsce, „Kronika Zamkowa” 2013, nr 1-2 (65-66), s. 167.

${ }^{132}$ Rozmowa E. Więcek z Barbarą Minorczyk, byłą właścicielką dworu w Oleśnie, z dnia 23 VIII $2012 \mathrm{r}$. 
-odbiorczego Muzeum Ziemi Tarnowskiej szafy biblioteczne z Olesna wraz z 5000-7000 woluminów książek weszły w skład przedmiotów zarekwirowanych rodzinie Konopków ${ }^{133}$. Następnie szafy wraz z księgozbiorem zostały przekazane MBP w Tarnowie ${ }^{134}$. Archiwalia zabezpieczone w dworze zdeponowano w Archiwum Państwowym w Krakowie ${ }^{135}$. Obecnie zachowaną kolekcję Zbyszewskich i Iżyckich stanowią 344 tytuły w 312 woluminach oraz zbiór 22 telegramów z 1888 r. z życzeniami dla nowożeńców Józefa i Leonii z Dachowskich Iżyckich ${ }^{136}$. W obrębie zbioru znalazło się osiem starych druków i dziewięć tytułów prasowych. Pod względem językowym 66\% kolekcji to wydania w języku polskim, 19\% - w j. francuskim, 10\% - w j. niemieckim, $4 \%-\mathrm{w}$ j. angielskim i tylko $1 \%$ - po łacinie. Natomiast pod względem tematycznym badane wydawnictwa cechują się dużą różnorodnością, świadczącą o bogatych zainteresowaniach właścicieli księgozbioru.

Warto w tym miejscu zauważyć, że liczebność zachowanej kolekcji byłaby większa, gdyby nie dwa czynniki. Pierwszy to rozproszenie księgozbioru Konopków z Olesna w 1949 r. za sprawą podziału kolekcji podworskich znajdujących się w MBP w Tarnowie pomiędzy tarnowską bibliotekę, Bibliotekę Jagiellońską, Bibliotekę Uniwersytetu Wrocławskiego oraz składnicę książek w Katowicach - niestety podział ten został dokonany bez zachowania formalnej dokumentacji zawierającej m.in. wykaz tytułów, jakie przypadły danej bibliotece. Drugi czynnik to wieloletnie wypożyczanie czytelnikom książek z XIX i XX w., co naturalnie skutkowało zagubieniem i zniszczeniem poszczególnych tomów. Dzięki trzem pierwszym inwentarzom MBP powstałym po 1945 r. wiemy o co najmniej 23 książkach, które pochodziły z dworu w Oleśnie ${ }^{137}$. Adnotacje zawarte w uwagach wykazów nie podają jednak, czy były to książki należące do Zbyszewskich i Iżyckich, czy do Konopków.

Najstarsze druki to Kazania Przygodne z Inemi [!] Drobniejszemi pracami... Piotra Skargi ${ }^{138}$ wydane w 1610 r. w krakowskiej oficynie Andrzeja

${ }_{133}$ Archiwum Państwowe w Krakowie Oddział w Tarnowie [dalej: APwKOT], MOT $33 / 273 / 34$, Sprawozdanie z prac wykonanych przy zabezpieczaniu zbiorów bibliotecznych na terenie pow. tarnowskiego i dębickiego od dn. I II $1945 \mathrm{r}$.

${ }^{134}$ Nie wiadomo, gdzie obecnie znajdują się szafy z majątku Olesno. MBP w Tarnowie nie posiada na ten temat informacji. APwKOT, Spuścizna po dr. Marii Dziamie 277/0 Dokumenty związane z pracą na stanowisku kustosza Biblioteki Muzeum Ziemi Tarnowskiej, Protokół zdawczo-odbiorczy.

${ }^{135}$ Zob. M. Żychowska, Biblioteka Muzeum Ziemi Tarnowskiej, [w:] Muzeum Okręgowe w Tarnowie: dzieje i zbiory, pod red. S. Potępy, [Tarnów] 1979, s. 37-38.

${ }^{136}$ Zbiór 22 telegramów z kolekcji Iżyckich i Zbyszewskich. MBP w Tarnowie, sygn.: od 32 do 53 .

137 Zob. Inwentarze MBP w Tarnowie za lata 1945-1950, t. 1-3.

${ }^{138}$ P. Skarga, Kazania Przygodne z Inemi [!] Drobniejszemi pracami, o różnych rzeczah [!] wszelakim stanom należacych ks. Piotra Skargi ... teraz znowu przejrżane $i$ w jedne ksieggi dla snadniejszego używania zebrane..., Kraków 1610. MBP w Tarnowie, sygn. SD-212. 
Piotrkowczyka, oraz Skład abo Skarbiec znakomitych sekretów oekonomijej ziemiańskiej... Jakuba Kazimierza Haura ${ }^{139}$ wydany w Krakowie w 1689 r. u Mikołaja Aleksandra Schedla. Pozostałe druki pochodzą z XVIII w. i zostały opublikowane w języku niemieckim, francuskim lub łacińskim. Wśród tych pozycji warto zwrócić uwagę na rzadki druk Gespräch im Reiche der Todten zwischen Maria Theresia und Friedrich dem Zweiten... Johana Ferdinanda Gauma z $1787 \mathrm{r}^{140}$, wydany w Meksyku ${ }^{141}$, oraz Über das Leben und den Karakter der Kaiserin von Russland Katharina II, wydany w Altonie w 1797 r. ${ }^{142}$

Prasę wjęzyku polskim reprezentują cztery tomy „BibliotekiZagranicznej” z lat 1842-1844143; jeden rocznik „Dziennika Praw [Księstwa Warszawskiego]” z 1808 r. ${ }^{144}$, sześć numerów „Panoramy Literatury Krajowej i Zagranicznej” $\mathrm{z}$ lat 1836-1838 ${ }^{145}$, wybrane numery „Przeglądu Polskiego” $\mathrm{z}$ lat 1887-1888 ${ }^{146}$, jeden rocznik „Przewodnika Bibliograficznego” z 1878 r. ${ }^{147}$, pięć numerów „Pszczoły Polskiej” z 1820 r. ${ }^{148}$, sześć numerów „Rozrywek dla Dzieci” z 1828 r. ${ }^{149}$ oraz 24 zeszyty „Świata Dramatycznego” z 1839 r. ${ }^{150}$ Natomiast w języku francuskim zachował się jeden rocznik „La Glaneur de Varsovie" z 1842 r. ${ }^{151}$

Na pozostałą część kolekcji składają się książki z XIX i pierwszej połowy XX w. Najliczniejszą grupę stanowi literatura piękna - 35\%. Reprezentują

139 J.K. Haur, Sktad abo Skarbiec znakomitych sekretów oekonomijej ziemiańskiej. Na Polach wielkich y obszernych, w stawnym na wszytek świat Królestwie Polskim, przy miastach koronnych, przy miasteczkach gęstych i nasiadlych, przy wsiach okolicznych królewskich, slacheckich, duchownych i miejskich. Znaleziony, a za osobliwym staraniem i pracowita pilnościa dla dobra pospolitego i pożytku ludzi wszelkiego stanu do używania wykopany..., Kraków 1689. MBP w Tarnowie, sygn. SD-224. Drugi egzemplarz tego samego wydania jest przechowywany tylko w Muzeum im. Emeryka Hutten-Czapskiego w Krakowie.

140 J.F. Gaum, Gespräch im Reiche der Todten zwischen Maria Theresia und Friedrich dem Zweiten, wrinnen diser hohen Personen Leben und ... Thaten bis zu ihrem Tode unpartheyisch erzählt werden Stück 1-5, Mexico 1787. MBP w Tarnowie, sygn. SD-50.

${ }^{141}$ Miejsce wydania jest fikcyjne - zob. T. Freller, Ostalbreisende in der Postkutschenzeit : Ritter, Dichter, Abenteurer, Erfurt 2011, s. 119.

${ }_{142}$ Über das Leben und den Karakter der Kaiserin von Russland Katharina II. Mit Freymüthigkeit und Unparteylichkeit, Altona 1797.

143 „Biblioteka Zagraniczna: pismo tomami wychodzące: poświęcone przekładom wyborowych dzieł z historyi, filozofii, ekonomii politycznej i innych nauk i umiejętności”. Mowa o pozycjach MBP w Tarnowie, sygn. od C-91617 do C-91620.

${ }^{144}$ MBP w Tarnowie, sygn. C-25318.

${ }^{145}$ MBP w Tarnowie, sygn. C-31936.

${ }^{146}$ MBP w Tarnowie, sygn. od C-39621 do C-39624 oraz C-183921 i C-183923.

${ }^{147}$ MBP w Tarnowie, sygn. Mag-178681.

${ }_{148}$ MBP w Tarnowie, sygn. od Mag-178935 do Mag-178939.

${ }_{149}$ MBP w Tarnowie, sygn. od Mag-179010 do Mag-179015.

150 „Świat Dramatyczny: dziennik poświęcony teatrowi, jego kronice, literaturze, historyi, żywotom, powieściom, humorystyce, nauce i zabawie". MBP w Tarnowie, sygn. C-31934 i C-31935.

${ }^{151}$ MBP w Tarnowie, sygn. C-26740. 
ją głównie autorzy polscy. Uzupełnieniem tego działu są książki z zakresu historii literatury i literaturoznawstwa $-8 \%$. Drugą co do wielkości grupę tworzą publikacje o tematyce społeczno-politycznej - 23\%. Trzecią zaś - książki z zakresu historii - 11\%. Ponadto w kolekcji występują: książki z zakresu nauk matematyczno-przyrodniczych $-8 \%$ oraz wydawnictwa encyklopedyczne, słowniki, leksykony - 3\%. W zbiorze nie brak tytułów na temat modnego w XIX w. spirytyzmu czy dotyczących coraz prężniej rozwijających się nauk biologiczno-medycznych. Dobrym przykładem są m.in. podręcznik dla studentów medycyny Ludwika Bierkowskiego Wstęp do anatomii ciała ludzkiego... ${ }^{152}$, prace Karola Darwina ${ }^{153}$, Paula Gibiera Spirytyzm... ${ }^{154}$, Ludwika Natansona Teoryja jestestw idiodynamicznych ${ }^{155}$, Antoniego Skórkowskiego Rys nauki o śmierci ${ }^{156}$.

Pod względem miejsca wydania dominują książki opublikowane w Warszawie -105 tytułów. Natomiast $\mathrm{z}$ innych polskich ośrodków najwięcej tytułów zostało wydrukowanych w Krakowie (40 wol.) oraz Poznaniu (35). Znaczną część książek opublikowano w Paryżu - 60 tytułów oraz w Lipsku - 33 tytuły. Wśród wydawców najwięcej książek zostało wydanych u Napoleona Kamieńskiego w Poznaniu (20 wol.), Gebethnera i Wolffa w Warszawie (12), w oficynie Dentu w Paryżu (11). Bardzo prawdopodobne, że część publikacji oficyn zagranicznych przywiozła ze swoich podróży P. Zbyszewska.

Wśród serii wydawniczych możemy spotkać polskie wydawnictwa, np.: „Wydawnictwo Dzieł Tanich” Adama Wiślickiego, „Wybór Przekładów z Wzorowych Pisarzów Zagranicznych” Henryka Natansona, „Zbiór Pisarzów Polskich” z drukarni Antoniego Gałęzowskiego w Warszawie, „Bibliotekę Krakowską" Towarzystwa Miłośników Historii i Zabytków Krakowa, „Bibliotekę Kieszonkową Klasyków Polskich” Breitkopfa i Haertela z Lipska, oraz zagraniczne: paryskie „Bibliothèque Contemporaine” od Calmanna Lévy'ego i „Nouveaux Résumés Historiques Collection” od Pagnerre'a, czy „Collection of British Authors” Bernharda Tauchnitza z Lipska.

W kolekcji znajdują się zarówno książki z oprawami przygotowanymi na zamówienie właścicieli księgozbioru, jak i z oryginalnymi oprawami

${ }^{152}$ L.J. Bierkowski, Wstęp do anatomii ciała ludzkiego: dla uczniów poświęcających się umiejętności lekarskiej, Kraków 1850. MBP w Tarnowie, sygn. C-91898.

${ }^{153} \mathrm{~Np}$. należące do P. Zbyszewskiej wydania rozpraw K. Darwina: The descent of man and selection in relation to sex in two volumes, London 1871. MBP w Tarnowie, sygn. C-26428; The expression of the emotions in man and animals, London 1872. MBP w Tarnowie, sygn. C-26427.

154 P. Gibier, Spirytyzm: studium historyczno-krytyczne i doświadczalne, objaśnione drzeworytami w tekście, Warszawa 1889. MBP w Tarnowie, sygn. C-89945.

155 L. Natanson, Teoryja jestestw idiodynamicznych, Warszawa 1883. MBP w Tarnowie, sygn. Mag-178895.

156 A. Skórkowski, Rys nauki o śmierci (tanatologija), Warszawa 1883. MBP w Tarnowie, sygn. C-89946. 
wydawniczymi - zarówno tekturowymi, jak i broszurowymi. Oprawy płócienne lub skórkowe wykonane na zamówienie dla wydawnictw z XIX i XX w. były stosunkowo skromne, jedynie niektóre posiadały pokryte złotą farbą tłoczenia na grzbiecie. W przypadku starych druków brak jednorodnych opraw oraz informacji na temat introligatorów. Tytuły te są oprawione w brązową lub czarną skórkę oblekającą deskę, a trzy tytuły zyskały współczesną oprawę introligatorską. Wklejki zachowane i w starodrukach, i w późniejszych wydawnictwach są skromne, jednobarwne. Prasa oraz większość polskich wydawnictw seryjnych na ogół nie podlegała oprawie i posiadała oryginalne broszurowe oprawy poszczególnych numerów.

Warto w tym miejscu nadmienić, że większość dziewiętnasto- i dwudziestowiecznej części kolekcji zachowała się w stanie średnim lub złym. Wiele książek ma poniszczone, poplamione i zakurzone okładki. Na niektórych egzemplarzach widać również ślady działalności owadów. Część jest też zagrzybiona i niekompletna.

Charakterystyczne dla kolekcji są naklejane na górnym brzegu książek i czasopism papierowe znaczki z numerem w obrębie księgozbioru. Niestety kolejni właściciele naklejali na stare oznaczenia kolejne, nowsze i w ten sposób te pierwsze stały się częściowo nieczytelne. Najnowsze na-

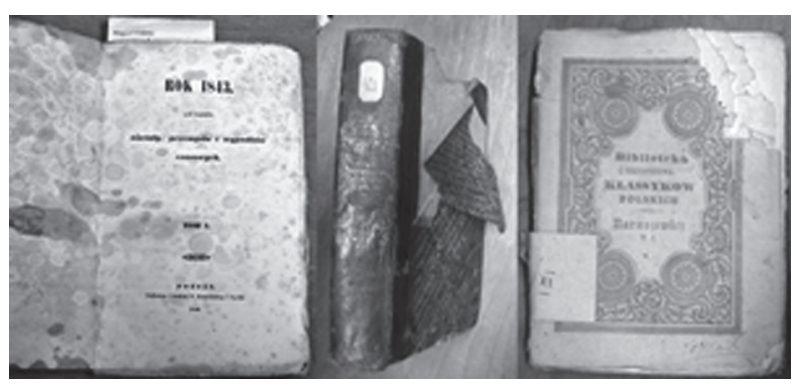

Fot. 1. Trzy różne przykłady zniszczeń: (od lewej) zagrzybienie, nadpalenie i oberwanie oprawy. Źródło: MBP w Tarnowie, sygn.: Mag-178880, Mag-178482, Mag-178856. Zdjęcie: M. Sobol-Kiełbania

klejki znalazły się na 312 woluminach i ich umieszczenie należy przypisać L. Iżyckiej lub jej córce Marii, żonie Jana M.L. Konopki z Olesna. Przypuszczenie to wynika z faktu, że naklejki znalazły się na książkach zarówno z proweniencjami rodziny Zbyszewskich, jak i Czackich oraz właśnie Iżyckich z Zatorów, a na tomach księgozbioru Konopków z Olesna brak takiego oznakowania ${ }^{157}$. Mogło ono być kontynuowane przez Leonię po śmierci męża lub wprowadzone dopiero przed ślubem Marii z Janem M.L. Konopką w 1919 r., by wydzielić część księgozbioru, którą miała wnieść w wianie mężowi. Najwyższy zachowany numerek w kolekcji to 5244 i znaj-

${ }^{157}$ Warto tu zauważyć, że w MBP w Tarnowie zachowały się tylko trzy książki z Olesna, będące własnością Jana M.L. Konopki. 
duje się on na książce należącej do G. Zbyszewskiego ${ }^{158}$. Dodatkowo często numer danej książki zapisano ołówkiem lub czerwoną kredką na okładce czy stronie tytułowej. Starsze typy naklejek należały m.in. do Z. Zbyszewskiego oraz P. Zbyszewskiej.

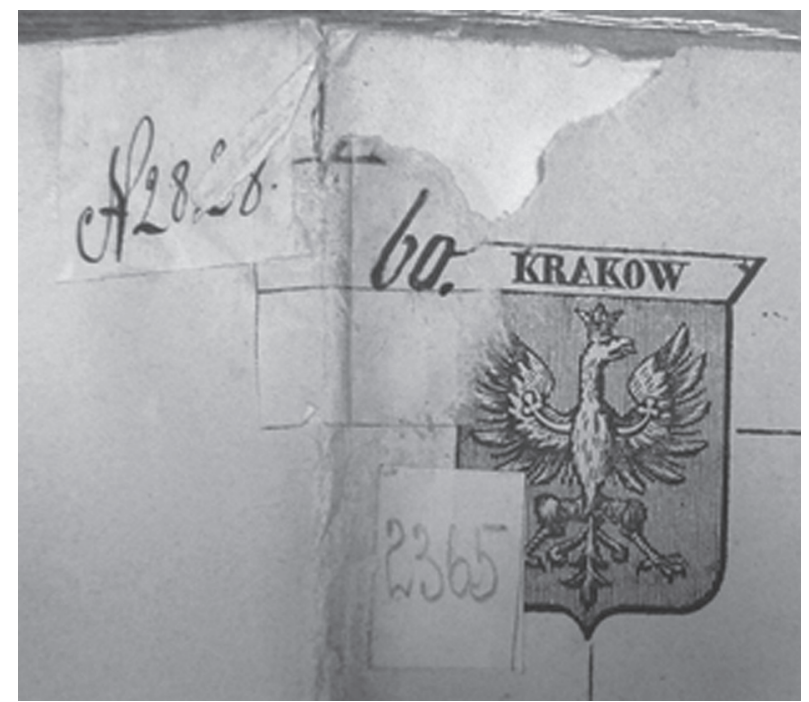

Fot. 2. Trzy różne naklejki z numeracją. Numerek Iżyckich „2365”. Źródło: MBP w Tarnowie, sygn: C-55467. Zdjęcie: M. Sobol-Kiełbania

Wśród znaków własnościowych brak superekslibrisów czy ekslibrisów wklejanych wewnątrz książki. W kolekcji można spotkać tylko jedną pieczęć agronoma Edmunda Grodzkiego ${ }^{159}$. Inną, najczęściej spotykaną formą proweniencji w kolekcji okazały się być podpisy odręczne. Najwięcej, bo 27 autografów zostawili po sobie G. Zbyszewski oraz P. Zbyszewska - siedem podpisów. Z rodziny Zbyszewskich swoje autografy złożyli również Z. Zbyszewski ${ }^{160}$ - cztery oraz M. Zbyszewska - trzy. Ponadto w kolekcji można znaleźć sześć bezimiennych podpisów „Zbyszewski”. Z rodziny Iżyckich najczęściej podpisywali się Olga i Józef - po cztery podpisy. Natomiast po

158 J. Kiliński, Pamiętniki Jana Kilińskiego szewca - a razem putkownika 20 regimentu, Warszawa 1830. MBP w Tarnowie, sygn. C-25291.

159 Prawdopodobnie był to zamordowany w Katyniu doktor prawa, dyrektor Oddziału Banku Związku Spółek Zarobkowych S.A. we Lwowie, porucznik rezerwy Edmund Grodzki (1892-1940). O samej postaci zob. Katyń. Księga Cmentarna Polskiego Cmentarza Wojennego, część 1, oprac. zespół pod kier. M. Tarczyńskiego, red. J. Snitko-Rzeszut, Warszawa 2000, s. 187. Wolumin z pieczęcią E. Grodzkiego to: W. Smoleński, Dzieje narodu polskiego. Wyktad popularny na podstawie ostatnich badań naukowych, cz. 3, Warszawa 1898. MBP w Tarnowie, sygn. Mag-178338.

${ }^{160} \mathrm{~W}$ przypadku Z. Zbyszewskiego jest to faksymile podpisu. 
dwa podpisy zostawiły Leonia i Maria Iżyckie. Z rodziny Czackich w kolekcji znajdziemy w sumie cztery podpisy należące do Marii Konstancji ${ }^{161}$ i Wiktora Czackiego. Odnotowano też 27 pojedynczych autografów, wśród których można wymienić podpisy m.in. Antoniego Szuszkowskiego ${ }^{162}$, A. Łubieńskiej ${ }^{163}$, K. Łaniewskiego ${ }^{164}$, Juli Jabłońskiej ${ }^{165}$, Leona Rzewuskiego $^{166}$, Aleksandra Pilara ${ }^{167}$. Niestety nie jest możliwe ustalenie, czy podpisy te miały charakter dedykacyjny, czy własnościowy i w jaki sposób książki nimi opatrzone stały się częścią księgozbioru Zbyszewskich i Iżyckich.

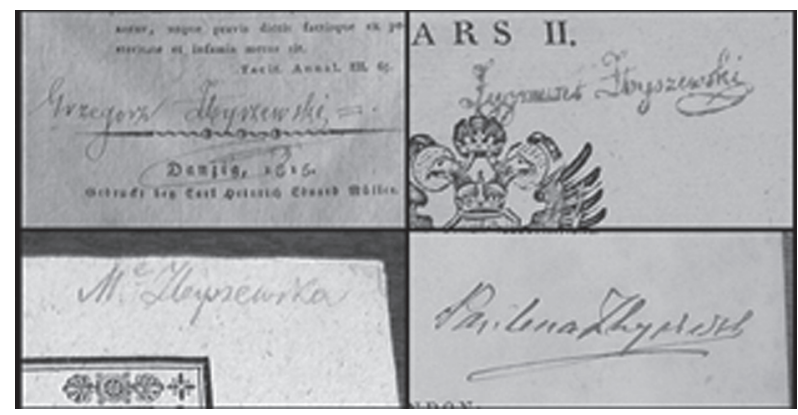

Fot. 3. Przykładowe podpisy (od lewego górnego rogu):

G. Zbyszewskiego, Z. Zbyszewskiego (faksymilia podpisu), M. Zbyszewskiej, P. Zbyszewskiej. Źródło: MBP w Tarnowie, sygn.: C-35942, SD-423, C-31935, C-26427. Zdjęcie: M. Sobol-Kiełbania

W kolekcji nie brak też dedykacji. Odnotowano ich w sumie dwanaście. Najciekawsze skierowane są do P. Zbyszewskiej. Warto tu zwrócić uwagę

${ }^{161}$ Maria Konstancja Czacka (1825-1865) była siostrą O. Iżyckiej - zob. Maria Czacka z Czacza h. Świnka, [online] <http://www.sejm-wielki.pl/b/3.529.17> (7.08.2015).

${ }_{162}$ Prawdopodobnie jest to podpis mjr. A. Szuszkowskiego - na jego temat zob. Antoni Szuszkowski, [online] <https://pl.wikipedia.org/wiki/Antoni_Szuszkowski> (7.08.2015). Podpis widnieje na: A. Bieńkowski, O powszechnym pokoju, Warszawa 1830. MBP w Tarnowie, sygn. Mag-179046.

${ }^{163}$ Nie udało się ustalić pełnego imienia A. Łubieńskiej. Jej podpis widnieje na: E.G. Bulwer Lytton Lytton, England and the English, L[ondon?] 1841. MBP w Tarnowie, sygn. A-90560.

${ }^{164} \mathrm{Nie}$ udało się ustalić pełnego imienia K. Łaniewskiego. Jego podpis widnieje na: J.I. Kraszewski, Ostatnia z ksiąząt słuckich: kronika z czasów Zygmunta Trzeciego, t. 2, Wilno 1841. MBP w Tarnowie, sygn. P-90398.

${ }^{165}$ Le centième anniversaire de l'indépendance Amèricaine célébré par les Polonais, Paris [1876]. MBP w Tarnowie, sygn. C-55420.

${ }^{166}$ T. Moore, The works of Thomas Moore, Leipsic [Leipzig]1826. MBP w Tarnowie, sygn. C-26430.

${ }^{167}$ C. Nepos, Cornelii Nepotis Vitae, Lipsiae 1855. MBP w Tarnowie, sygn. Mag-177258. 
na dedykację od warszawskiego wydawcy Michała Kępińskiego ${ }^{168}$ i autorów Adolfa Smorczewskiego ${ }^{169}$ oraz Antoniego Hołowińskiego ${ }^{170}$. Wpisy te moga wskazywać na to, że P. Zbyszewska zajmowała się też korektą wydawniczą. Wśród dedykacji o charakterze rodzinnym warto wyróżnić podarunek dla Pelagii Iżyckiej ${ }^{171}$ oraz prezent wielkanocny z 1916 r. od Leonii Iżyckiej dla córki Mariii ${ }^{172}$.

Na drukach z omawianego księgozbioru można też natrafić na nieliczne notatki czytelnicze zapisane na marginesach czy też luźnych kartkach.

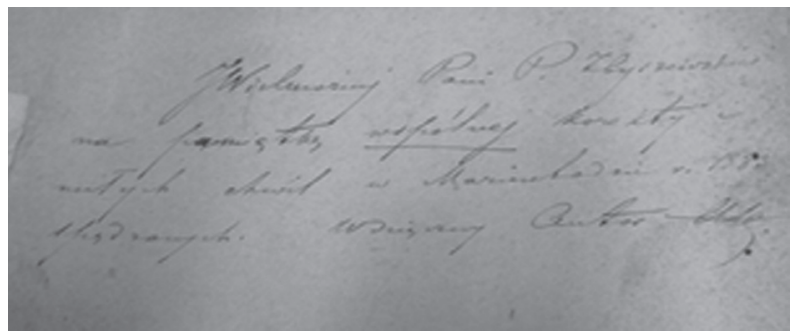

Fot. 4. Dedykacja dla P. Zbyszewskiej od A. Hołowińskiego. Źródło: MBP w Tarnowie, sygn.: Mag-179039. Zdjęcie: M. Sobol-Kiełbania

Jeśli oceniać kolekcję nie tylko pod kątem znaczenia dla historii regionu tarnowskiego, lecz także pod względem unikalności samych wydań poszczególnych książek, można (dzięki porównaniu np. z bazami KaRo, NUKAT lub ogólnoświatową bazą WorldCat) zauważyć, że aż 32 tytuły z kolekcji nie występują w innych polskich bibliotekach lub są w maksymalnie trzech instytucjach. Warto tu wspomnieć np. o publikacjach w formie nadbitek z czasopism: pracy A. Hołowińskiego $O$ geometrycznem ttumaczeniu fal sfygmografu z 1883 r. ${ }^{173}$, której to nie odnotowuje Bibliografia polska Karola

${ }^{168}$ Dedykacja na: Ksią̇̇ka jubileuszowa dla uczczenia pięćdziesięcioletniej działalności naukowej prof. dr. Szokalskiego, pod red. J. Talko, Warszawa 1884. MBP w Tarnowie, sygn. Mag-178326.

169 Mowa o: A. Smorczewski, Listy z Czech, Warszawa 1873. MBP w Tarnowie, sygn. Mag-178421.

${ }_{170}$ Dedykacja na: A. Hołowiński, O geometrycznem tłumaczeniu fal sfygmografu, [b.m.] 1883. MBP w Tarnowie, sygn. Mag-179039.

${ }^{171}$ Mowa o Pelagii Wielhorskiej z Iżyckich, siostrze J. Iżyckiego, właściciela majątku Zatory. Dedykacja od „P.H.” z 1878 r. na: G. Brugier, Geschichte der deutschen National-Litteratur: Nebst kurzgefasster Poetik für Schule und Selbstbelehrung, Freiburg 1874. MBP w Tarnowie, sygn. C-24464.

172 Była to publikacja: B. Chlebowski, Pisma Bronistawa Chlebowskiego, t. 1-4, Warszawa 1912. MBP w Tarnowie, sygn. C-13369 do C-13372.

${ }^{173}$ A. Hołowiński, dz. cyt. 
Estreichera, czy dziele A. Smorczewskiego Włochy tegoczesne ${ }^{174}$, rzadkim podręczniku Wypisy niemieckie na klassę trzecia języka niemieckiego ${ }^{175} \mathrm{czy}$ Atanazego Raczyńskiego Katalog der Raczynskischen Bilder-Sammlung ${ }^{176}$, polskim tłumaczeniu Ryszarda Lwie Serce Waltera Scotta (z warszawskiej oficyny Natana Glücksberga) ${ }^{177}$, Teoryi karnej Kanta ze stanowiska jego ogólnej nauki o rozumie praktycznym autorstwa Edmunda Krzymuskiego ${ }^{178}$ oraz Paula de Kocka Cyruliku Paryskim z oficyny Merzbacha ${ }^{179}$. W skład kolekcji wchodzi też 76 tytułów, które są dostępne w nielicznych polskich bibliotekach ${ }^{180}$ (to w większości publikacje obcojęzyczne).

W tym miejscu nasuwa się wniosek, że ze względu na wyjątkowość kolekcji Zbyszewskich i Iżyckich MBP w Tarnowie powinna postarać się o ukończenie katalogowania książek wchodzących w skład tego zbioru oraz zadbać o przechowywanie ich w najlepszych możliwych w obecnej sytuacji lokalowej placówki warunkach. Warto byłoby też książki zniszczone poddać odgrzybianiu oraz naprawie introligatorskiej. W przyszłości, jeśli zostaną pozyskane odpowiednie środki, powinno się fragmenty zachowanej kolekcji Zbyszewskich i Iżyckich zdigitalizować. Omawiany księgozbiór, podobnie jak i inne kolekcje podworskie, jest wykorzystywany zarówno przez pracowników MBP w Tarnowie, np. podczas tworzenia wystaw tematycznych, prowadzenia lekcji bibliotecznych propagujących historię książki, jak i przez czytelników, którzy w oparciu o ten zasób piszą prace naukowe, czy wykorzystują informacje np. $\mathrm{z}$ prasy dziewiętnastowiecznej $\mathrm{w}$ amatorskich badaniach historyczno-genealogicznych. Księgozbiór Zbyszewskich i Iżyckich, podobnie jak inne kolekcje podworskie w MBP w Tarnowie, jest nie tylko interesującym źródłem, które można wykorzystać przy opracowywaniu ciekawych

174 A. Smorczewski, Włochy tegoczesne, cz. 3: Kraina alpejska i Sabaudya, Warszawa 1888. MBP w Tarnowie, sygn. Mag-178874; tenże, Włochy tegoczesne, cz. 4: Toskania, Warszawa 1889. MBP w Tarnowie, sygn. Mag-178875. Oba tomy stanowią odbitkę z „Biblioteki Warszawskiej”.

175 Wypisy niemieckie na klassę trzeciąjęzyka niemieckiego, Warszawa 1821. MBP w Tarnowie, sygn. Mag-178565.

176 A. Raczyński, Katalog der Raczynskischen Bilder-Sammlung, Berlin 1843. MBP w Tarnowie, sygn. Mag-178595. Drugi egzemplarz tego samego wydania jest przechowywany w Bibliotece Narodowej w Warszawie, a trzeci - w National Art Library w Londynie.

177 W. Scott, Ryszard Lwie Serce w Palestynie: romans historyczny, t. 4, Warszawa 1826. MBP w Tarnowie, sygn. Mag-178396. Tomy 1-3 można znaleźć np. w Bibliotece Narodowej w Warszawie.

178 E. Krzymuski, Teoryja karna Kanta ze stanowiskajego ogólnej nauki o rozumie praktycznym, Kraków 1882. MBP w Tarnowie, sygn. Mag-178993. Inne egzemplarze tego wydania są dostępne np. w Bibliotece Narodowej i Bibliotece Naukowej im. Zielińskich Towarzystwa Naukowego Płockiego.

179 P. de Kock, Cyrulik Paryski, t. 1-4, Warszawa 1834. MBP w Tarnowie, sygn. Mag-180134 do Mag-180136.

${ }^{180}$ Naturalnie istnieje możliwość, że dana placówka nie ukończyła katalogowania zbiorów starszych, przez co przedstawione liczby mogą ulec zmianie. 
prac z zakresu bibliologii, historii lub literaturoznawstwa, lecz także przede wszystkim cennym i niepowtarzalnym dziedzictwem mienionej epoki.

\section{Streszczenie}

Ziemię lubelską i Mazowsze zamieszkiwały w XIX i XX w. liczne rody ziemiańskie, których przedstawiciele zapisali się w historii tych regionów Polski. Takim przykładem są rodziny Zbyszewskich h. Topór i Iżyckich h. Bończa, zamieszkujących Markuszową, Kurowo oraz Zatory. Warto zwrócić uwagę na działaczkę społeczną i przyjaciółkę Narcyzy Żmichowskiej - Paulinę Zbyszewską (1822-1892); sędziów pokoju: Grzegorza Zbyszewskiego (1789-1856), Józefa Iżyckiego (1787-1865) i jego syna Józefa (1822-1893) oraz działaczkę społeczną i bywalczynię warszawskich salonów - Leonię z Dachowskich Iżycką (1862-1929). Za sprawą rodzinnych koligacji część księgozbiorów tych rodzin trafiła do dworu Konopków w Oleśnie na Powiślu Dąbrowskim.

Konopkowie zgromadzili w swoim dworze imponującą bibliotekę, której sporą część stanowiła kolekcja książek Zbyszewskich i Iżyckich. Publikacje te od 1945 r. i reformy rolnej przechowuje Miejska Biblioteka Publiczna im. Juliusza Słowackiego w Tarnowie. W kolekcji dominuje literatura piękna, głównie w języku polskim. Ponadto w zbiorze występują licznie książki publikowane w seriach lub wydawnictwach wielotomowych. Tomy posiadają różnego typu oprawy wydawnicze polskie i zagraniczne. W kolekcji znalazły się liczne znaki proweniencyjne: znaczki z numeracją księgozbioru, pieczęcie i podpisy odręczne oraz dedykacje. W zachowanym fragmencie księgozbioru rodzin Zbyszewskich i Iżyckich znajdują się unikatowe i rzadkie wydania dostępne w nielicznych ośrodkach w Polsce. Z tego powodu kolekcja nie tylko ma znaczenie dla historii regionu tarnowskiego, lecz także jest cennym dziedzictwem narodowym.

Slowa kluczowe: badania proweniencyjne - biblioteki prywatne XIX i XX w. - Miejska Biblioteka Publiczna im. Juliusza Słowackiego w Tarnowie. 


\section{Summary}

\section{The Zbyszewski and the Iżycki Families' Book Collection in the Tarnów Public Library Collection}

In the $18^{\text {th }}$ and $19^{\text {th }}$ centuries there were numerous landed gentry families living in the Lubelskie and Mazovia regions whose members were inscribed in the history of these regions. The families of Zbyszewski (Topór coat of arms) and the Iżycki (Bończa coat of arms) who lived in Markuszowa, Kurowo and Zatory were two remarkable examples of such families. It is worth to mention several important representatives of both families: Paulina Zbyszewska (1822-1892), a social activist and a friend of Narcyza Żmichowska; three magistrates: Grzegorz Zbyszewski (1789-1856), Józef Iżycki (1787-1865) and his son Józef (1822-1893); Leonia Iżycka née Dachowska (1862-1929), a social activist and frequent visitor of the Warsaw salons. Part of the Zbyszewski and Iżycki families' book collection was held in the Konopkowie manor house in Oleśno in the Dąbrowski district of the Tarnów region because of the family ties with the Konopkowie family.

The Konopkowie family gathered an impressive book collection in their manor house, and part of their collection was the Zbyszewski and the Iżycki families' collection. These books have been held in the Public Library in Tarnów since 1945 (and the time of the agricultural reform in Poland). The collection consists mainly of literary works written in. However, there are also numerous books which were published in series and in multivolume editions. These books have different types of covers: Polish and foreign ones. There are numerous bookplates in these books: ex libris with collection numbers, stamps, seals, personal signatures and dedications. Morover in the preserved Zbyszewski and Iżycki families' collection, might be found unique and very rare editions, which are rarely represented in other institutions in Poland. Due to above this collection is regarded as the one of major importance, not only in the context of the history of the Tarnów region, but also nationally - it is part of the precious national heritage.

Key words: provenance research - private libraries in the $19^{\text {th }}$ and $20^{\text {th }} \mathrm{c}$. - J. Słowacki Municipal Public Library in Tarnów. 
